\title{
Strategic Repositioning of Tax Administration in Nigeria Through Transfer Pricing
}

\author{
Onyeka-Iheme Chimeruo Victory ${ }^{1}$, Akintoye Ishola Rufus ${ }^{2}$ \\ ${ }^{1}$ Department of Accounting, Christopher University, Mowe, Nigeria \\ ${ }^{2}$ Department of Accounting, Babcock University, Ilishan-Remo, Nigeria
}

Email address:

onyeka-iheme3579@student.babcock.edu.ng (Onyeka-Iheme C. V.), akintoyei@babcock.edu.ng (Akintoye I. R.)

\section{To cite this article:}

Onyeka-Iheme Chimeruo Victory, Akintoye Ishola Rufus. Strategic Repositioning of Tax Administration in Nigeria Through Transfer Pricing. Journal of Finance and Accounting. Vol. 9, No. 5, 2021, pp. 190-199. doi: 10.11648/j.jfa.20210905.12

Received: September 3, 2021; Accepted: September 23, 2021; Published: September 29, 2021

\begin{abstract}
The need to diversify revenue sources in Nigeria through taxation cannot be over-emphasized especially with the advent of Corona Virus (COVID-19) which seem to strengthen international trading and the tax administrators a key to achieving the desired tax revenue. It is therefore pertinent tat tax administration in Nigeria is properly positioned to properly handle tax issues around transfer pricing for an enhanced tax revenue in Nigeria. In this study, the researcher evaluated the different components that could strategically reposition tax administration in Nigeria for optimum tax revenue through Transfer Pricing. This research paper employed theories and empirics in examining all the variables involved in the discussion. There was a relatively broad review of literatures covering the prospects, challenges as well as the efforts of government towards the optimization of Transfer Pricing Taxation (TPT). Survey and descriptive research designs were employed for this study and SPSS was employed for data analysis. There was performance of descriptive statistics on the demographic information of the respondents while the influence of the variables on the strategic repositioning of tax administration through transfer pricing in Nigeria were determined through the use of T-test data analysis. Reliability test was done using Cronbach's alpha to measure the reliability of the instrument. The findings revealed that tax administrators and other stakeholders are undecided about the adequacy of various provisions in the tax laws/regulations to handle domestic transfer pricing matters such as evasion and aggressive avoidance schemes leading to Base Erosion and Profit Shifting; the capacity, capability and motivation of tax administrators for same purposes. Recommendations were offered.
\end{abstract}

Keywords: Aggressive Avoidance Scheme, Federal Inland Revenue Service, Optimize Tax, Strategic Repositioning, Tax Administration, Transfer Pricing

\section{Introduction}

\subsection{Background}

The year 2015 was a landmark year in the history of Transfer Pricing Taxation (TPT) both in Nigeria and the world at large as it was the year in which the Organization for Economic Co-operation and Development (OECD) concluded the action plans against Base Erosion and Profit Shifting (BEPS). Prior to 2015, tax administrators (especially in the developing nations like Nigeria) faced a lot of administrative challenges occasioned by complex business arrangement issues that they didn't know how best to tackle in order to achieve the best taxing result for the taxing nation accruing from Transfer Pricing (TP) activities of
Multinational Corporations (MNCs). Although there have been calls and efforts put in place to diversify and increase the revenue stream through taxation for the Nigeria, such efforts in themselves are not without challenges. Taxation in particular is coming up on the spotlight because of high international sales and transactions traffic in the recent times especially in this COVID-19 era where almost all transactions are online and borderless enabling more international trades.

Unfortunately, the reactivation of interest in the generation of tax revenue has led to various problems which includes but not limited to the proliferation of taxes and abuse of taxing powers [46]. Taking a look at the issue of corporate tax, many problems could be said to be related with tax and the collection of taxes and these include the administrative, 
compliance, bad governance, human capital building as well as corruption challenge among others $[18,27]$. It will interest you to note that these tax administrative issues are still very active in hindering the optimization of tax revenue accruable from MNCs hidden in TP [19]. Today, tax administrators all over the world are paying close attention to TP due to the globalization of businesses and the increase in foreign income and the possibility of mispricing which could lead to tax avoidance as well as tax evasion [5, 51].

Tax administrators are faced with the task of determining the best price for intra-group transactions so as to solve the problem of mispricing which often leads to low profitability. Therefore, governments have given power to tax administrators to be able to make some adjustments to the taxable income calculated so as to make corrections on TPs that are not at arm's length [56]. TPT as a tool is explained and it is for the prevention of TP manipulation even though tax authorities are often faced with some negative issues in the process of auditing internal TPs due to the fact that MNCs are faced with a strong incentive for evading taxes as well as manipulating TPs to retain as much profits as they can in a divisions that are located in jurisdictions with low taxes [36]. If arm's length TP is inadequately administered, TP can be costly for all stakeholders and this will lead to lengthy audit, litigations, TP adjustments, potential nondeductible penalties and double taxation $[16,38]$.

Furthermore, MNCs often indulge in actions that will enable them to shift their income from high tax jurisdictions to those with low tax rates through TPs already determined. To this end, administrators of tax from other economies reveal concerns increasingly about income shifting activities of MNCs internationally which serves as a method to reduce their taxes globally [34, 45]. Also, price manipulation make room for firms to gain major tax benefits in business as long as it is carried out within the framework of the law and this leads to shunning of disclosure of their actual incomes thereby hinder the financial potential of the economy [42]. Income shifting through the instrumentality of TP is a huge challenge to tax authorities of nations of which Nigeria is not an exception and there is need to find a lasting solution to it as much as possible.

The Nigerian tax system has been bedeviled with a lot of negativity which can mostly be as a result of the inadequacy or lack of the use of Information Technology in tax administration [3]. Provision of adequate and up to date working tools to tax administrators is a matter that cannot be over emphasized especially in these days of rapid growth in the use of technology and knowledge. Again, tax administrators are vigilant to the TP problem and thus has become of more importance especially as with the advent of globalization. Even though there are a lot of research works that are available, only those which are related to the use of $\mathrm{TP}$ as a resource allocation, strategic use, cash management purpose and management control use are narrated [44]. It is therefore needful that adequate working tools are made available to tax administrators to enable them track and crack all these sharp practices by MNCs TP.

Tax authorities' weak ability to enforce the TP existing laws and regulations, MNCs employ TP plots to misuse tax regulations available in developing countries of which Nigeria is not left out [6]. Following all the above mentioned problems and more, it will be seen that there is a need to come up with a workable guideline or regulations that will reposition the tax administration in Nigeria for maximum and effective TPT. The release of the last action package on October $5^{\text {th }}, 2015$ and part of OECD's BEPS action plan is an attempt to aid members of the G20 to revamp the rules to better deal with the complex structures that make profits shifting possible through TP. Adu, stated that the BEPS action plans consist of 15 actions targeted at 3 main objectives which are: introducing logical agreement in the local rules that affect activities across boarder, strengthening the particulars of great importance in the existing standards, and enhancing transparency as well as certainty [4].

Furthermore, Income Tax (Transfer Pricing) Regulations, 2018 of Nigeria was enacted with five objectives: appropriate taxing basis, proper tools to fight tax evasion, avoidance of double taxation, fairness and certainty (TP Regulations, 2018). Five and two years down the line respectively, to what extent have these objectives been achieved and how can the tax administration be repositioned to duly maximize these objectives so as to optimize the tax revenue accruable from TPT? These are the focus of this study. This study is divided into various sections starting from the review of extant literatures which included the review of concepts and theories in TP, then the methodology section describes the design adopted for this study as well as the sampling technique employed. The next section is Data presentation and analysis and the final section dealt with the discussion of findings and implications.

\subsection{Statement of the Problem}

The ability of MNCs to carry out BEPS and the failure of tax administration in Nigeria to generate optimum tax revenue from MNCs has led to the need to strategically reposition tax administration in Nigeria and this has led to researches on the best actions to be taken or not to be taken by the various stakeholders in pursuit of the desired repositioning of tax administration in Nigeria.

\subsection{Objective of the Study}

This study's main objective was to evaluate variables that could enhance tax administration in Nigeria so as to help reposition it strategically for optimum tax revenue from MNCs as it affects transfer pricing. The following are the specific objectives:

To evaluate the extent the policies, rules and regulations are sufficient to prevent BEPS in Nigeria.

To appraise the extent tax administrator's efforts in the prevention of evasion and avoidance.

To assess the extent policies, rules and regulations are adequate in regulating transfer pricing practice domestically.

To determine the extent to which tax administrators are empowered to handle matters relating to transfer pricing issues. 


\subsection{Research Questions}

In order to address the aforementioned objectives, the following research questions were asked to guide the study:

1) To what extent do policies, rules and regulations adequately prevent BEPS in Nigeria?

2) To what extent do tax administrators' efforts prevent evasion and avoidance in Nigeria?

3) To what extent do policies, rules and regulations adequately regulate transfer pricing practice domestically?

4) To what extent are tax administrators empowered to handle matters relating to transfer pricing issues?

\section{A Review of Extant Literature}

Tax as a word has been variously defined by several authors one of which is that tax is an imposed contribution by the government on the income of its residents compulsorily as well as on their profits, services, goods or properties. These residents may be individuals or corporate persons, settlements and trusts [40]. Tax is a compulsory payment levied by the government on the profits, income or wealth of individuals, group of individuals and corporate persons and it is imposed to help government to raise fund in order to attain the economic and social goals of the nation $[37,42]$. The Nigerian system of taxation has tax policy, laws and administration as its make-up and they are all intended to work harmoniously to attain the nation's economic goal $[1,33]$.

Tax administration is a sub set of the tax system. It is the implementation of tax laws in assessing and collecting taxes while a tax administering body is an organization designed and empowered by law to enable government in the various tiers to economically, efficiently and effectively collect revenue from tax payers [21]. Tax agency responsible for TP in Nigeria is the Federal Inland Revenue Service (FIRS) and like every other tax administrations in the world is also faced with various challenges especially in handling issues arising from TP. The society where the administration of tax functions is speedily changing and have to meet up with demands that are increasing and strong hopes that are regularly growing from their stakeholders, including new demands for modernized services rendered by the government [23, 39]. One of such sophisticated processes that the tax administrator is faced with is the matter of TP carried out by MNCs.

The tax administrators are expected to be well educated and enlightened on TP regulations and models of operation of these MNCs to be able to optimize tax revenues that should accrue from the TP transactions of the MNCs. Onoja and Odoma stated that tax administration mainly on both the implementation and enforcement of legislations on tax as well as regulations both involving activities such as identification and registration of tax payers, tax returns handling and information of the third-party, examination of tax returns for completeness and correctness, tax obligations assessment, enforcement of tax and rendering of other services to taxpayers [41]. The efforts of collecting tax revenues in MNCs that are involved in TP cannot be achieved unless there is a strategic repositioning of the administration to guarantee proper collection of taxes and to reduce evasion of tax especially in the midst of this our rapidly changing and sophisticated business world. TP being the setting of internal prices for internal (intra-firm) use selling of goods, rendering of services, purchase of intangibles and capital flows within an MNC.

TP has been an issue of debate as it is blurring the thin line between avoidance and tax evasion. The pre-tax profits earned by each party through cross-border transactions are affected by TP including the amount of corporation tax due the countries involved [29]. TP is the method of determining prices of goods, intangibles and services in transactions between related parties or companies that are commonly controlled. Rathke, opined that TP as a strategy involves the movement of profits from location with high-tax to the ones with low-tax rates, in order to treat a larger percentage of the total profits to lower tax rates [45]. TP is used in in intra branch transfers among MNCs whose focus is on the sale of goods and provision of services among other things and who can be really seen as both legal and economic tool for the reduction of their tax burden [4, 47].

Profit shifting is the arranging of the activities of a business firm resulting to low or no tax burden, by moving their profits from the locations with activities bringing about the profits to other areas where it is reported and these are majorly connected with the actions that artificially isolate taxable income from those transactions that bring about the profits $[2,13]$. MNCs situated in high-tax zones can "transfer the prices" of income as well as the associated expenses and move their earnings to a low-tax zones so as to minimize or completely avoid taxation with the help of TP [9]. These activities all lead to avoidance of income tax and may even escalate to tax evasion if it becomes aggressive [22]. According to Ohnuma and Kato, as far as the many companies which aim to go abroad usually referred to as MNCs are concerned, light taxation countries are the preferable locations for companies with high corporate taxes [35]. The external reasons why some companies embark on TP could be to reduce tariffs, taxes or duties, as well as the foreign and domestic taxes as well as to strengthen the foreign subsidiary and transfer pricing could be abused through manipulation of the transfer pricing [7].

\subsection{Strategic Repositioning of Tax Administration Through Transfer Pricing}

\subsubsection{Policies, Guidelines and Regulations on BEPS}

Prior to the introduction of TP regulations and action plans, tax administrators and scholars lamented the lack of regulations that are up to date and thoroughly captured the various activities in the MNCs that could lead to tax avoidance and evasion. It is believed that this happens largely because the existing international tax rules are outdated [4]. Also, because many of these structures are not illegal, tax authorities were not able to counter them under existing tax 
frameworks but with introduction of the OECD BEPS action plans, the tax administrators now can counter these structures. The guidelines for the international TP prior to 2015 contain high level of doubt which are causing a lot of disputes among MNCs and the tax authorities [26, 54, 44].

In an attempt to find a lasting solution to the challenges that tax administrators encounter in tax auditing the transactions of MNCs especially in the area of BEPS done through the instrumentality of transfer pricing, the BEPS action plans where reeled out. The OECD believes that the issue of double non-taxation happens on a significant scale and has tried to curtail this through several of the BEPS action plans. In particular Actions 2 to 5 which are Hybrid Mismatch, CFC Rules, Interest Deductions and Harmful Tax Practices respectively attempt to address BEPS issues arising from a lack of coherence in the international tax rules adopted by different countries. The objective of the policy among others is to prevent what countries view to be excessive interest deductions mainly on intragroup debt which is used as a tool for BEPS [14].

The aim is to ascertain that profits are taxed where economic transactions producing the profits are carried out along with where value is created but irrespective of how well these action plans are, implementation by tax administrators are still faced with challenges. BiereenuNnabugwu and Abah stated that statutory stipulations on the issue of transfer payments are fraught with administrative problems at the implementation level and the problem of how to discern or distinguish transfer and non - transfer payments outside the few obvious cases thereby making the administration of the statute problematic [12]. "Despite formal imposition of this requirement its effectiveness highly depends on stringency of tax authorities, regarding both the means to confirm the application of the principle and acceptance of proofs prepared by MNCs to sustain pricing choices" [30].

Onoja and Odoma found out that complexities in administrative tax have a huge effect on the level of tax compliance which are seen in the complexity in tax procedures, rules, laws and computations that discourage the level of tax payment [41]. Even with the fact that "arms' length" standard has been the base of taxation regime internationally since the onset of the $20^{\text {th }}$ century, many experts have seen it to be among the main enablers of profitshifting majorly because of those transactions that appear hard to settle in a comparable markets such as intangible assets and intellectual property rights [8, 17, 28]. With these provisions available to the tax administration, the issue of implementation becomes a matter to reconsider and the need to reposition the tax administration in Nigeria becomes imperative.

\subsubsection{Tax Evasion and Avoidance}

BEPS is a phrase used to describe complex tax avoidance schemes used by multinationals to minimize their overall tax burden and it is a project that attempts to ensure that enough taxation of MNCs by limiting their aggressive tax avoidance methods. MNCs skillfully wipe off their tax base in economies with high-taxes and move the earnings to those with low-taxes through the instrumentality of tax planning skills. Though these methods are not illegal on their own but misusing them for tax evasion reasons is considered problematic for a lot of reasons [28, 52]. Shukla, Pandey, and Lingam stated that developing countries suffer the loss of an estimated amount of $\$ 100$ - $\$ 240$ billion of revenue annually due to BEPS practices [50]. If these losses are to be curtailed, the tax administrators needs to be well equipped and the administration strategically repositioned to tackle these practices through the comprehensive implementation of the TP regulations.

Tax authorities believe the contractual information on intercompany transactions do not always reflect the actual substance of the transactions. Because of this, many intercompany transactions are priced incorrectly, leading to base erosion. In a bid to counter this, the OECD has set out several action plans that seek to make sure that pricing will follow substance rather than contractual arrangements. These include Actions 6 and 7 which are Treaty Abuse and Artificial Avoidance of PE. There are also Actions 8 to 10 (Aligning TP Outcome with Value Creation) which primarily deal with changes to the OECD guidelines for TP. Tax planning that is aggressive tends to exploit the differences in systems of taxation by maximizing opportunities through the tax system technicalities or of mismatches existing between two or more tax systems for the purpose of avoiding or evading tax liability [25, 57].

Pedro and Jose's study produced a result showing that taxation of foreign profits from home can minimize incentives attached to income shifting and also, limited tax credit rule appears to be a bit inefficient measure for taxation of foreign profits [43]. Companies related internationally can use TP to move earnings from one company to another to achieve the desired earnings, tax benefits and also reduce the merged profits or to break into new markets while increasing its market share in the existing market Talab, Flayyih, and Yassir opined that if MNCs could pick any price at will, it could move the totality of its taxable earnings to economies having lower income tax rates but tax administrators have coordinated efforts on arm's length standard for ascertaining if the resulting allocation of taxable earning is justifiable for tax reasons [55].

$\mathrm{Abu}$, et al on erosion of tax bases showed that the magnitude income shifting by MNCs from low-income economies to tax havens is among of the main problems affecting the development of these countries negatively and suggested that necessary legal framework should be put in place to tackle tax avoidance through BEPS [2]. While Shukla, et al stated that tax treaties unarguably made its contribution in international taxation but however, they are also difficult to amend and renegotiate leading to rigidity which is also harmful to both the tax payer and the tax regime [50]. To this effect, a tax administrator who is not well equipped and knowledgeable will find it difficult to implement the action plan. 
Again, because the transactions of these MNCs are somewhat shrouded in secrecy through complex business arrangements, tax administrators are not able to adequately access their transactions in order to assess their taxes. The action plans on transparency seek to ensure that tax authorities have access to information from the other side of the transaction to allow them make reasonable assessments of BEPS activities. These include Actions 11 to 13 and they are Measuring and Monitoring BEPS, Disclosure of Aggressive Tax Planning as well as TP documentation and Country by Country (CbyC) reporting respectively. The action plans envisages methods for data collection and monitoring and also advises for the disclosure of tax planning arrangements that are aggressive to aid tax authorities in detecting harmful practices. The adoption of "Automatic Exchange of Information (AEoI)" as a new worldwide standard to fight against evasion of tax is broadly viewed as a basic advancement in MNC's tax cooperation as it will help the tax administrators to share and obtain information about an MNC tax payer operating in countries other than Nigeria [28].

Therefore, the OECD BEPS project according to Stuart is a good effort in trying to protect tax bases in situations where they are expected to be taxed and hinder double taxation of MNCs [54]. Proper implementation of the plan will produce a balanced effect on both the tax payer and tax administrators which requires that the tax administrator be properly enlightened to succeed in the implementation. Secrecy in rendering financial services is one of the things that aids tax evasion especially as it is the economies that make them available to non-indigenes, allowing them to avoid the disclosure of their wealth and income to other nations where they are also liable to taxes which is the reason why international exchange of bank account and related information was introduced and was welcomed as an effective solution to tax evasion. There is therefore the need to position and empower tax administrators to enable them maximize these provisions for maximum effectiveness.

\subsubsection{Tax Administrator's Empowerment}

Other issues trailing the matter of tax administrator's need to be strategically repositioned so as to enable them maximize the objectives of the TP regulations and action plans are the issue of capacity and capabilities of the tax administrator. Cazacu (Neamtu) opined that the issue of TP is quite complex not just for tax authorities but also for multinationals, being one of the most relevant tax issue they encounter today [15]. As part the attempts to reposition tax administration in Nigeria, FIRS in 2013 created a special division to handle the transfer pricing and other international tax related matters named Transfer Pricing Division. This Division was later upgraded to a full Department in 2015 known as International Tax Department (ITD) to fully tackle the issues arising from transfer pricing and other international tax related matters. But despite this, the administration is still frost with some challenges.

Enahoro and Olabisi are of the opinion that shortage of qualified tax personnel, inadequate equipment of the tax personnel, low education level of tax personnel and sharp practices of these tax personnel pose a serious threat to tax administration [20]. The education, enlightenment, equipment and empowering the tax administrator need not be overemphasized. Also, Liu, et al opined that despite the imposition of TP requirement formerly, but the desired effectiveness mainly depends on how stringent the tax authorities are, on the method to confirm the application of the principle as well as the acceptance of prepared proofs by MNCs to maintain their pricing choices [29]. Barsch, Heckemeyer and Olbert carried out a study found that having disputes with local tax authorities are very likely and that tax risk is bigger, if the tax department has a more supreme authority over TP decisions and that internal coordination averagely seems not to be affected by the allocation of rights to make decisions to the taxation departments [10].

\subsection{Theoretical Framework}

The theory explored in this study and upon which this study is based is the Optimal Tax Theory.

Optimal Tax Theory

Optimal Tax theory was developed by Ramsey, F. P. in 1927. This is a theory that concerns itself with the study of the designation and implementation of a tax system that maximizes a social welfare function taking into consideration some economic constraints. The theory states that a tax system ought to be chosen to with maximization of a social welfare function in mind $[31,32]$. It is a theory that tries to determine the set of taxes and transfers that will maximize the social function through a typical model using a limited number of goods and with the use of empirical realities and it uses a welfarist approach [11]. The theory's aim is to address questions like: should income or commodity taxes be used by government? If commodities, how would tax rates differ among goods? How progressive is the tax system expected to be?

The optimal taxation theory is said to be normative, that it mainly assumes that tax policies are made by dictators who are benevolent and also respect individuals' preferences including preference for some 'social' equality which produces a standard with which to measure actual public policies [53]. The theory posits that tax system that is optimal should have an equal proportionate change in the quantities of each good instead of having each price change by an equal proportion [24]. Optimal tax theory aims at taxing leisure goods more and basic goods less in order to encourage working. It tries to balance the marginal social benefit from activities that generate externalities [48]. An optimal tax system which encourages labor and will not encourage BEPS by MNCs because it is encourages a good reward for hard work. In order to optimize taxes from MNCs and to discourage BEPS, a good and optimal tax system is required.

\section{Methodology}

Cross sectional survey design was adopted for this study for data collection purposes and the population comprised of stakeholders in the administration of taxes in Nigeria. The 
research design is survey and descriptive research. In this study, the researcher evaluated the different components that could strategically reposition tax administration in Nigeria for optimum tax revenue through transfer pricing. The design identified four group variables, which have been adjudged to have some level influence on tax administration as it affects TP in Nigeria. The population included all FIRS staff in International Tax Department (ITD), a simple randomly sampled members of staff of FIRS in Large Tax Audit Offices (LTA), staff members of KPMG Professional Services and PEDABO Associates Limited (renowned Firms in Accounting \& Tax Professional Services) and tax lecturers in Christopher University, all in Nigeria.

The construct validity of the instrument was guaranteed by giving the research instrument to a Professor of Accounting and Finance in the Department of Accounting of Babcock University and a Manager in FIRS Tax Audit Department to show the extent to which each of the questionnaire items is relevant to the underlying construct it indicates. T-test was conducted to test the variables. SPSS version 20.0 was used for the purpose of analyzing the data. Cronbach-Alpha's test of reliability was conducted to ensure the reliability of the test instrument.

\section{Results and Discussion of Findings}

\subsection{Descriptive Analysis}

100 questionnaires were distributed and 90\% were returned which is 90 copies in all. The respondents' categories which was based on age showed an age range of 20 to above 50 years. While the gender revealed 64 (71.1\%) to be male, while $26(28.9 \%)$ were female. As for educational qualification, HND/B.Sc. were 57 (64\%), MBA/M.Sc. were $22(24.7 \%), \mathrm{PhD}$ were $6(6.7 \%)$ and others were $4(4.5 \%)$. The instrument used for data collection was designed by the researcher and comprised of five sections: section 1 contained information on respondents demographic data (gender, age and educational qualification); section 2 was on adequacy of policies, rules and regulations to curtail BEPS; section 3 was on preventing tax evasion and avoidance using TP; 4 deals with policies, rules and regulations on handling TP issues in Nigeria; while section is on the empowerment of tax administrators to handle TP issues for optimum tax revenue. The questionnaire was constructed using a fivepoint Likert scale numbered 1, 2, 3, 4 and 5. The rating system adopted followed the subsequence of: $1=$ Strongly Agree (SA), 2=Agree (A), 3=Undecided (U), 4=Disagree (D), $5=$ Strongly Disagree (SD).

The reliability test was 0.749 . To answer the research questions, the mean results were labelled agree and disagree and rated on the basis of 1.00-1-99 (strongly agree); 2.002.99 (agree); 3.00-3.99 (undecided); 4.00-4.99 (disagree) and 5.00-5.99 (strongly disagree). Using a two-tailed test, we will "reject" on both tails of the normal curve. The critical values were those that cut off the area on each end of the curve which is equal to $0.05 / 2$. Also having the t-test at $p$ and the level of significance as $<0.05$.

\subsection{Empirical Analysis and Discussion}

Research Question One: To what extent do policies, rules and regulations adequately prevent BEPS in Nigeria?

Table 1. T-test analysis.

\begin{tabular}{|c|c|c|c|c|c|c|}
\hline & \multicolumn{6}{|c|}{ Test Value $=0$} \\
\hline & \multirow{2}{*}{$\mathbf{T}$} & \multirow{2}{*}{ Df } & \multirow{2}{*}{ Sig. (2-tailed) } & \multirow{2}{*}{ Mean Difference } & \multicolumn{2}{|c|}{ 95\% Confidence Interval of the Difference } \\
\hline & & & & & Lower & Upper \\
\hline BEPS2 & 29.966 & 89 & .000 & 3.289 & 3.07 & 3.51 \\
\hline BEPS1 & 30.901 & 89 & .000 & 3.611 & 3.38 & 3.84 \\
\hline
\end{tabular}

$\mathrm{Df}=\mathrm{N}-1 ; 95 \%$ Confidence Interval.

Research question 1 evaluated if the policies, rules and regulations adequately prevent BEPS in Nigeria. The results showed the degree of respondent's answers to the adequacy of policies, rules and regulations to prevent BEPS in Nigeria. Table 1 showed that most of the respondents were undecided about the adequacy of the tax policies, rules and regulations to address BEPS in Nigeria. Furthermore, a $t$-test of significance analysis was conducted and the results showed that the policies, rules and regulations do not adequately prevent BEPS with the result from $t$-test ranging from 29.966 to 30.901 at $p<.000,2$-tailed. By implication, none of the respondents agreed that there has been adequate and deliberate action plans taken by FIRS to mitigate BEPS. None also agreed to the fact that there are sufficient policies, rules and regulations to prevent BEPS in Nigeria. These findings are in line with $[4,53,43,12,40]$.

Research Question Two: To what extent do tax administrators' efforts curb tax evasion and aggressive avoidance schemes in Nigeria?

Table 2. T-test analysis.

\begin{tabular}{lllllll}
\hline & Test Value $=\mathbf{0}$ & & & & \\
\cline { 2 - 7 } & & T & \multirow{2}{*}{ Df } & \multirow{2}{*}{ Sig. (2-tailed) } & Mean Difference & \multicolumn{2}{c}{ 95\% Confidence Interval of the Difference } \\
\cline { 5 - 8 } & & 89 & .000 & 2.122 & Lower & 2.30 \\
\hline EVAV1 & 23.092 & 89 & .000 & 2.122 & 1.94 & 2.95 \\
EVAV2 & 24.591 & &
\end{tabular}

$\mathrm{Df}=\mathrm{N}-1 ; 95 \%$ Confidence Interval. 
Research question 2 was aimed at determining if tax administrators' efforts to curb tax evasion and aggressive avoidance schemes in Nigeria. The statistical analysis result which are the Mean (M) and Standard Deviation (SD) for this study's respondents' answers to items showed that they agreed that tax administrators' efforts to curbing tax evasion and excessive avoidance are adequate as shown in Table 2 with the $t$-test ranging from 23.092 to 24.591 . The answers of the respondents' are significant at $p<.000,2$-tailed. The findings of this study are in line with [43, 49], while [55] are not in line calling for further studies to ascertain a clearer position.

Research Question Three: To what extent do policies, rules and regulations adequately regulate transfer pricing practice domestically?

Table 3. T-test analysis.

\begin{tabular}{lllllll}
\hline & \multicolumn{2}{c}{ Test Value $=\mathbf{0}$} & & & \\
\cline { 2 - 7 } & $\mathbf{T}$ & \multirow{2}{*}{ Df } & Sig. (2-tailed) & Mean Difference & \multicolumn{2}{c}{ 95\% Confidence Interval of the Difference } \\
\cline { 6 - 8 } & & 89 & .000 & 3.067 & 2.82 & Upper \\
\hline TPPGR1 & 24.687 & 89 & .000 & 3.367 & 3.12 & 3.62 \\
TPPGR8 & 26.748 & 89 & .000 & 3.611 & 3.38 & 3.84 \\
TPPGR12 & 31.187 & 89 & .000 & 3.867 & 3.67 & 4.06 \\
TPPGR13 & 39.084 & 89 &
\end{tabular}

$\mathrm{Df}=\mathrm{N}-1 ; 95 \%$ Confidence Interval.

Research question 3 was aimed at determining if tax policies, rules and regulations adequately regulate $\mathrm{TP}$ practice domestically. The M and SD statistical analysis for this study's responses to items revealed that respondents agreed while the rest are undecided that tax policies, rules and regulations are adequate to regulate $\mathrm{TP}$ practices domestically. The results as shown in Table 3 further highlight the position of the respondents with the $t$-test ranging from 24.687 to 39.084 , the responses are also significant at $p<.000,2$-tailed. With none disagreeing to the fact that tax policies, rules and regulations are adequate to regulate TP practices domestically, implies that the problem could be on implementation. This study's findings are in line with [40, 54, 28].

Research Question Four: To what extent are tax administrators empowered to handle matters relating to transfer pricing issues?

Table 4. T-test analysis.

\begin{tabular}{|c|c|c|c|c|c|c|}
\hline & \multicolumn{6}{|c|}{ Test Value $=0$} \\
\hline & \multirow{2}{*}{$\mathbf{T}$} & \multirow{2}{*}{ Df } & \multirow{2}{*}{ Sig. (2-tailed) } & \multirow{2}{*}{ Mean Difference } & \multicolumn{2}{|c|}{ 95\% Confidence Interval of the Difference } \\
\hline & & & & & Lower & Upper \\
\hline WCRTTO1 & 29.204 & 89 & .000 & 3.378 & 3.15 & 3.61 \\
\hline WCRTTO2 & 29.501 & 89 & .000 & 3.222 & 3.01 & 3.44 \\
\hline WCRTTO5 & 28.419 & 89 & .000 & 3.378 & 3.14 & 3.61 \\
\hline OTIS3 & 30.801 & 89 & .000 & 3.400 & 3.18 & 3.62 \\
\hline
\end{tabular}

$\mathrm{Df}=\mathrm{N}-1 ; 95 \%$ Confidence Interval.

Research question 4 evaluated if tax administrators are adequately empowered to handle matters relating to transfer pricing issues. The results showed the extent respondents answered to the adequacy of tax administrator's empowerment, capacity and capability to handle matters relating to TP issues in Nigeria. Table 4 showed that all the respondents were undecided about the adequacy of the tax capacity to handle TP issues in Nigeria. Furthermore, the $t$-test of significance analysis was conducted and the results showed that the tax administrators are not adequately empowered with the needed capacity and capability to handle TP issues in Nigeria with the $t$-test ranging from 28.419 to 30.801 at $p$ $<.000$, 2-tailed. By implication, none of the respondents agreed that there has been adequate and proper empowerment of the tax administrators to be able to handle TP issues in Nigeria. None also agreed to the fact that there are sufficient working tools to adequately handle TP activities in Nigeria. These findings are in line with $[15,20,29,10]$.

\subsection{Implications of Findings}

This study's findings have some implications for a range of users of accounting information and these implications are outlined as follows:

Regulators/Tax Authorities and Standard setters: They can adopt these findings from the research to further look into the adequacy of transfer pricing laws that are available and to further adapt them to suit the domestic situation of transfer pricing in Nigeria. This is to ensure that they are suitable to prevent BEPS and evasion and avoidance as much as possible.

Tax Administrators/Field Officers: The implication to tax authorities that there is the need to ensure that the tax administrators are adequately trained and equipped on the available regulations on transfer pricing, empowered and well-motivated to carry out their transfer pricing taxation activities appropriately. 
Tax law enforcement departments should be empowered and held accountable to carry out their over sight functions so as to ensure that available transfer pricing regulations are duly complied with by all relevant tax payers.

Potential Investors: These findings imply that potential investors should consider transfer pricing activities adopted by the MNCs before making investment decisions to ensure that they are not encouraging transfer mispricing of these MNCs in their quest for profitability.

Future researchers: The findings of the this study will serve as an additional contribution to knowledge and also as a reason for them to carry out further research with the consideration of other variables and factors that will help achieve a strategic repositioning of tax administration in Nigeria for optimum tax revenue.

\section{Conclusion and Recommendations}

\subsection{Conclusion}

The study examined strategic repositioning of tax administration through transfer pricing in Nigeria. The results show various variables that could contribute to the strategic repositioning of tax administration in Nigeria to bring about optimum tax revenues from MNCs in Nigeria. This paper reviewed the various concepts and challenges in tax administration especially as it affects handling transfer pricing matters in Nigeria. The findings revealed that tax administrators and other stakeholders are undecided about the adequacy of various provisions in the tax laws/regulations to handle domestic transfer pricing matters such as evasion and aggressive avoidance schemes leading to Base Erosion and Profit Shifting; the capacity, capability and motivation of tax administrators for same purposes. To ensure strategic repositioning of tax administration in Nigeria, these challenges must need to be properly addressed.

\subsection{Recommendations}

The following the findings and conclusion of this research work, these recommendations are made:

1) There has to be periodic review by all stakeholders to bring about adequate policies, rules and regulations in line with global best practices to prevent BEPS and the associated evasion and aggressive avoidance of taxes through transfer (mis)pricing.

2) Deliberate and adequate action plans should be implemented by FIRS to mitigate BEPS by MNCs.

3) Proper and adequate education and enlightenment of tax administrators to enable them have a firm grip of the existing transfer pricing laws/regulations and OECD action plans for efficiency in carrying out their transfer pricing taxation duties.

4) The definition of Permanent Establishment (PE) laws should be revisited to make it robust enough to avoid artificial avoidance especially in this e-commerce era.

5) Proper motivation of staff members of FIRS could be revisited and the provision of right working tools as well as efficient and customer friendly technology will be needed to further position the service for optimum productivity.

6) Monitoring of the existing TP regulations is paramount to ensure their proper implementation.

\subsection{Contribution to Knowledge}

The following contributions to knowledge are made from this research work:

Concept: The study was on strategic repositioning of tax administration through transfer pricing in Nigeria. The results show various variables that could contribute to the strategic repositioning of tax administration in Nigeria to bring about optimum tax revenues from MNCs in Nigeria.

Theory: The study discovered that Laffer curve theory of taxation is still quite relevant as well as optimal tax theory. MNCs in the first place may not attempt to practice BEPS through transfer pricing if the tax rates are appropriate and optimal. The study supports that governments should endeavor to make tax laws and policies that will both encourage labor and payment of taxes.

Literature: The findings of the study bring to the limelight that tax administration in Nigeria could be strategically repositioned to optimize tax revenues from MNCs through proper handling transfer pricing matters within the ambits of the existing laws and transfer pricing regulations. It should also serve as a reference point to other scholars and researchers.

Empirics: This work contributes to existing findings and empirics that repositioning of tax administration strategically will enhance transfer pricing taxation in Nigeria through proper making and implementation of transfer pricing laws as well educating and empowering the tax administrators.

Policies: In the course of this work, it was observed that many tax administrators are either not aware or are not familiar with existing laws/regulations and policies on transfer pricing issues. Policy makers and Tax Authorities should also consider proper education of the tax administrators in the field offices for optimum result. There is also the need to properly domesticate transfer pricing regulations from OECD to enable its effective application in Nigeria.

\section{References}

[1] Abiola, J \& Asiweh, M. (2012). Impact of Tax Administration on Government Revenue in a Developing Economy - A Case Study of Nigeria. International Journal of Business and Social Science, 3 (8), 99-113.

[2] Abu, M. M., Bello, U. \& Mohammed, Z. (2020). Base Erosion and Profit Shifting (BEPS) in Low-Income Nations by the Multinationals: A Critical Review of Literature. Journal of Critical Reviewers, 7 (5), 502-509.

[3] Adeyeye, G. B. (2019). Improving Tax Administration through Technology Innovation in Nigeria (A Case Study of Federal Inland Revenue Service). Annals of Spiru Haret University, Economic Series, 19 (1), 31-63. 
[4] Adu, S. (2016). 15 Reasons why October 5th is a Day to Remember in the Nigerian Tax Terrain. Tax Article on BEPS (1), PWC. www.pwc.com.

[5] Afuberoh, D. \& Okoye E. (2014). The impact of taxation on revenue generation in Nigeria: A study of Federal Capital Territory and selected States. International Journal of Public Administration and Management Research, 2 (2), 22-47. Retrieved from http://www.remss.com. 10/09/2018.

[6] Agana, J. A., Mohammed, A. \& Zamore, S. (2018). International Transfer Pricing and Income Shifting in Developing Countries: Evidence from Ghana. International Journal of Emerging Markets, 5, 181-219.

[7] Akhidime, A. E. (2011). International Transfer Pricing Regulation: Nigerian Experience. JORIND 1 (9), 350-357.

[8] Baistrocchi, E. A. (2013). The International Tax Regime and the BRIC World: Elements for a Theory. Oxford of Journal of Legal Studies, 33 (4), 733 -766.

[9] Barker, J., Asare, K. \& Brickman, S. (2017). Transfer Pricing as a Vehicle in Corporate Tax Avoidance. The Journal of Applied Business Research, 33 (1), 9-16.

[10] Barsch, S., Heckemeyer, J. H. \& Olbert, M. (2019). Transfer Pricing and the Decision-making Authority of the Tax Function in Multinational Companies. D20, D74, D81, H25, 1-53.

[11] Batchelder, L. L. (2019). Optimal Tax Theory as a Theory of Distributive Justice. NYU School of Law, Draft.

[12] Biereenu-Nnabugwu, M. N. \& Abah, N. C. (2015). Reflection on the Realities and Challenges of Income Tax Administration in Nigeria. Journal of Policy and Development Studies, 9 (4), $71-80$.

[13] Burgers, I. \& Mosquera, I. J. V. (2017). Corporate Taxation and BEPS: A Fair Slice for Developing Countries. Erasmus Law Review, 10 (1), 29 -47.

[14] Burnett, C. (2019). Interest Deductibility: Implementation of BEPS Action 4 and the Future of Transfer Pricing of Intragroup Finance. Bulletin for International Taxation, 73 (6/7), 325-331.

[15] Cazacu (Neamtu), A. L. (2017). Transfer Prices - An International Problem. Junior Scientific Researcher, III (2), $19-25$.

[16] Cheng, W. \& Zhang, D. (2010). The Arm's Length Principle, Transfer Pricing and Foreclosure under Imperfect Competition. China Economic Management Academy, Working Paper Series 09004 (Econ), 1-22.

[17] Cobham, A. \& Jansky, P. (2018). Global Distribution of Revenue Loss from Corporate Tax Avoidance: Re-estimation Country Results. Journal International Development, 30, 206 -232 .

[18] Edori, D. S., Edori I. S. \& Idatoru A. R. (2017). Issues and Challenges Inherent in the Nigerian Tax System. American Journal of Management Science and Engineering. 2 (4), 52-57.

[19] Emmanuel, S. N. (2018). The Impact of Tax Administration on Revenue Generation in Gombe State, Nigeria. Scholedge International Journal of Management \& Development, 5 (8), $86-95$.

[20] Enahoro, J. A. \& Olabisi, J. (2012). Tax Administration and Revenue Generation of Lagos State Government. Research Journal of Finance and Accounting, 3 (5), 133-140.
[21] Esu, E. A. (2018). An Appraisal of Nigerian Tax System and the Implications of Electronic-Commerce Taxation. International Journal of Business, Economics and Management, 1-37.

[22] European Commission Recommendation of 6 Dec. 2012 on Aggressive Tax Planning C (2012) 8806 Final at 2.

[23] Ganyam, A. L., Ivungu, J. A. \& Anongo, E. T. (2019). Generation in Nigeria: Evidence from Benue State Tax Administration (2015-2018). International Journal of Economics, Commerce and Management, VII (7), 394-414.

[24] Gentry, W. M. (1992). Optimal Taxation. 307-309. 1000539optimal-taxation.pdf.

[25] Irma J. M. V. (2015). The OECD-BEPS Measures to Deal with Aggressive Tax Planning in South America and Sub-Saharan Africa: The Challenges Ahead. INTERTAX, 43 (10), 615-627.

[26] Kamerkar, A. N. \& Bhagwat, M. (2017). The Time and Motion Study in Chemical Industry. Journal of Business and Management, 19 (8), $31-36$.

[27] Kurawa, J. M. \& Saidu, H. (2018). Corporate Tax and Financial Performance of Listed Nigerian Consumer Goods. Journal of Accounting and Financial Management, 4 (4), 30 - 43.

[28] Lips, W. (2018). Great Powers in Global Tax Governance: A Comparison of the US Role in the CRS and BEPS, Globalizations, 1-17.

[29] Liu, L., Schmidt-Eisenlohr, T. \& Guo, D. (2017). International Transfer Pricing and Tax Avoidance: Evidence from Linked Trade-Tax Statistics in the UK. International Finance Discussion Papers 1214.

[30] Lohse, T. \& Riedel, N. (2013). Do Transfer Prices Laws Limit International Income Shifting? Evidence from European Multinationals. The International Platform of LudwigMaximilians University's Center for Economic Studies and Ifo Institute, Working Paper, No. 4404, 1-31.

[31] Mankiw, N. G., Weinzierl, M. \& Yagan, D. (2009). Optimal Taxation in Theory and Practice. Journal of Economic Perspectives, 23 (4), 147-174.

[32] Mirrlees, J. A. (1976). Optimal Tax Theory: A Synthesis. Institute of Technology, Massachussets, 176, 1-51, Digitized by the Internet Archives in 2011.

[33] Nwadialor, E. \& Ekezie, C. A, (2016). Effect of tax policy on economic growth in Nigeria (1994 - 2013). International Journal of Business Administration. 7 (1), 50 - 58. ISSN 1923-4007, E-ISSN 1923-4015.

[34] Ogbonna, G. \& Odoemelam, N. (2015). Impact of taxation on economic development of Nigeria: 2000-2013. Journal of Social and Policy Research Development, 9, 251-267.

[35] Ohnuma, H. \& Kato, K. (2015). Empirical Examination of Market Reaction to Transfer Pricing Taxation Announcement in Press: A Japanese Perspective. Journal of Modern Accounting and Auditing, 11 (1), 10-26.

[36] Ohnuma, H. \& Sakurada, J. (2017). Corporate Governance Issues regarding Transfer Pricing Taxation: Evidence from Japan. Asian Business Research, 2 (3), 58-73.

[37] Okoye, E. I. \& Gbegi, D. O. (2013). Effective value added tax: An imperative for wealth creation in Nigeria. Global Journal of Management and Business Research. 13 (1), Version 1.0, 90- 100 . 
[38] Olaoye, C. O. \& Owoniya, B. O. (2016). Effects of Taxation and Compliance on International Transfer Pricing Regulations in Nigeria (2008-2015). Research Journal's Journal of Management, 4 (10), 1-11.

[39] Omesi, I \& Nzor, Nuka P. (2015). Tax reforms in Nigeria: Case for value added tax. African Research Review: an International Multidisciplinary Journal, Ethiopia, 9 (4), S/No. 39, 277-287.

[40] Omodero, C. O. \& Ogbonnaya, A. K. (2018). Corporate Tax and Profitability of Deposit Money in Nigeria. Journal of Accounting, Business and Finance Research, 3 (2), 47 - 55.

[41] Onoja, E. E. \& Odoma, A. U. (2020). Assessing the Effect of Tax Administration on SMEs Tax Compliance Level in Kogi State. European Journal of Social Sciences, 3 (1), 15-29.

[42] Osho, A. E., Efuntade, A. O. \& Jemiseye-Dav, R. A. (2020). The Impact of Taxation on Transfer Pricing in Nigeria Economy. International Research Journal of Finance and Economics, 177, 139-151.

[43] Pedro, H. A. C. \& Jose, S. (2018). Time and motion study applied to a production line of organic lenses in Manaus Industrial Hub. Gestao Producao, Sao Carlos, 25 (4), 901 - 915.

[44] Pendse, J. S. (2012). International Transfer Pricing: A Review of Non-Tax Outlook. Procedia - Social and Behavioural Sciences, 37, 337-343.

[45] Rathke, A. A. T. (2015). Transfer Pricing Manipulation, Tax Penalty Cost and Impact of Foreign Profit Taxation. School of Economics, Business and Accounting, F23, H26, 1-19.

[46] Richards, N. U. (2019). Overview of the National Tax Policy and Its Implication for Tax Administration in Nigeria. NAUJILJ 10 (2), 42-50.

[47] Roberto, M. V. (2013). Evaluating Know-how for Transfer Price Benchmarking. Journal of Finance and Accounting, 1 (1), 27-38.
[48] Saez, E. \& Stantcheva, S. (2016). Generalized Social Marginal Welfare Weights for Optimal Tax Theory. American Economic Review, 106 (1), 24-45.

[49] Sansing, R. (2014). International Transfer Pricing. Foundations and Trends in Accounting, 9 (1), 1-57.

[50] Shukla, G., Pandey, S. K. \& Lingam, S. (2020). Tax Effects of Treaty Shopping and OECD's BEPS Implications. FIIB Business Review, 9 (2), 85-93.

[51] Smith, A. O. (2015). The Impact of Transfer Pricing on Financial Reporting: A Nigerian Study. Research Journal of Finance and Accounting, 6 (16), 208-218.

[52] Solilova, V. \& Nerudova, D. (2013). Transfer Pricing: General Model for Tax Planning. Ekonomicky Casopis, 61 (6), 597-617.

[53] Sørensen, P. B. (2007). The Theory of Optimal Taxation: What is the Policy Relevance? International Tax and Public Finance, 14: 383-406.

[54] Stuart, A. (2009). Transfer Pricing: A World of Pain, CFO Magazine. Svazic, T. (2019). Anti-BEPS Measures and Their Impact on Business Performance of Multinational Enterprises. Our Economy, 65 (4), 99-109.

[55] Talab, H. R., Flayyih, H. H. \& Yassir, Y. N. M. (2017). Transfer Pricing and its Effect on Financial Reporting: A Theoretical Analysis of Global Tax in Multinational Companies. International Business Management, 11 (4), 921-928.

[56] Talha, M., Alam, S. S. \& Sallehhuddin, A. (2005). Transfer Pricing and Taxation Implications Disclosure in Segmental Reporting: Malaysian Evidence. International Business \& Economics Research Journal, 4 (7), 31-40.

[57] Udoayang, J. O., Akpanuko, E. E. \& Asuquo, A. I. (2009). Multinational Transfer Pricing and International Taxation: What, Why, How and Reporting Challenges. An International Multi-Disciplinary Journal, Ethiopia, 3 (5), 165-181. 